\title{
The Role of Organic and Inorganic Amendments in Carbon Sequestration and Immobilization of Heavy Metals in Degraded Soils
}

\author{
Agnieszka Placek ${ }^{1}$, Anna Grobelak ${ }^{* 2}$, Joanna Hiller ${ }^{3}$, Wioleta Stepieñ ${ }^{4}$, \\ Paulina Jelonek $^{5}$, Marta Jaskulak, Malgorzata Kacprzak \\ ${ }^{1}$ Faculty of Infrastructure and Environment, Czestochowa University of Technology, \\ Dabrowskiego 69, 42-201 Czestochowa, Poland \\ e-mail: agnieszka.placek@o2.pl \\ ${ }^{2}$ Faculty of Infrastructure and Environment, Czestochowa University of Technology, \\ Dabrowskiego 69, 42-201 Czestochowa, Poland \\ e-mail: agrobelak@is.pcz.czest.pl \\ ${ }^{3}$ Faculty of Infrastructure and Environment, Czestochowa University of Technology, \\ Dabrowskiego 69, 42-201 Czestochowa, Poland \\ e-mail: hillerjoanna@gmail.com \\ ${ }^{4}$ Faculty of Infrastructure and Environment, Czestochowa University of Technology, \\ Dabrowskiego 69, 42-201 Czestochowa, Poland \\ e-mail: stepien.wioleta@wp.pl \\ ${ }^{5}$ Faculty of Infrastructure and Environment, Czestochowa University of Technology, \\ Dabrowskiego 69, 42-201 Czestochowa, Poland \\ e-mail: paulina.jelonek@poczta.fm \\ ${ }^{6}$ Faculty of Infrastructure and Environment, Czestochowa University of Technology, \\ Dabrowskiego 69, 42-201 Czestochowa, Poland \\ e-mail: martajaskulak@gmail.com \\ ${ }^{7}$ Faculty of Infrastructure and Environment, Czestochowa University of Technology, \\ Dabrowskiego 69, 42-201 Czestochowa, Poland \\ e-mail: mkacprzak@is.pcz.czest.pl
}

Cite as: Placek, A., Grobelak, A., Hiller, J., Stępień, W., Jelonek, P., Jaskulak, M., Kacprzak, M., The Role of Organic and Inorganic Amendments in Carbon Sequestration and Immobilization of Heavy Metals in Degraded Soils, J. sustain. dev. energy water environ. syst., 5(4), pp 509-517, 2017, DOI: http://dx.doi.org/10.13044/j.sdewes.d5.0166

\section{ABSTRACT}

To investigate the effect of organic and inorganic amendments on heavy metal immobilization in soil and organic carbon sequestration, a growth chamber study over a period of 18 months was conducted. Phytoremediation of two degraded soils, smelter-polluted soil and post-mining soil, was carried out using Scots Pine (Pinus Sylvestris L.) and Giant Miscanthus (Miscanthus $x$ Giganteus). The increase in organic carbon content for lake chalk amended soils was noted. In addition, the largest root biomass production after fertilization of heavy metal contaminated soil with lake chalk was observed. This soil additive increases soil $\mathrm{pH}$ and reduces heavy metal mobility, which finally minimizes the harmful effect of metals on plant life and growth. Root biomass production of Giant Miscanthus was significantly higher than Scots Pine root biomass for both soils. This may indicate better phytosequestration properties of Giant Miscanthus, especially in the case of land degradation due to mining and destruction of soil profiles.

\footnotetext{
${ }^{*}$ Corresponding author
} 


\section{KEYWORDS}

Carbon sequestration, Soil organic carbon, Heavy metal immobilization, Smelter soil, Post-mining land, Lake chalk.

\section{INTRODUCTION}

The Carbon dioxide $\left(\mathrm{CO}_{2}\right)$ released to atmosphere and other anthropogenic activities are documented as the cause of greenhouse effect which results in global warming. The soils are the main terrestrial pool for organic carbon. It is estimated that more than $75 \%$ of Earth's terrestrial soils contain 4 times more organic carbon than storage in living vegetation. Mining is one of the anthropogenic activities which leads to soil disturbances such as the accumulation of contaminants and loss of significant quantities of organic matter [1-3].

Some types of soil can lose up to 80 tons $\mathrm{C} / \mathrm{ha}$ emitted into atmosphere which has a significant impact on the amount of greenhouse gases in the atmosphere. Decreasing in soil organic carbon is strictly connected with numerous factors such: the loss of quantity of biomass returned to soil, changes in soil moisture and temperature, adverse $\mathrm{C}: \mathrm{N}$ ratio and lignin content, increase in soil erosion as well as decrease in soil aggregation. Enhancing as well as restoring soil quality can increase the concentration of Soil Organic Carbon (SOC) and thus decreasing the greenhouse effect. One of the methods used in soil organic carbon sequestration is biological phytoremediation [3-6]. Phytoremediation's techniques are frequently used and additionally, commonly accepted by society. Their advantages include: adaptability with respect to different types of soil, the requirement of a small financial outlay, an insignificant interference with the natural environment and the capability to recover some of the costs (e.g., through the sale of wood, biomass energy, compost) [7, 8]. Reforestation of degraded areas is one of the most effective and common ways of soil remediation and it also plays an important role in carbon sequestration. Forest areas cover about $29 \%$ of terrestrial lands and $60 \%$ of organic carbon stock is in terrestrial vegetation [9]. $\mathrm{CO}_{2}$ can be stored in plant tissues as well as in forest soils as humus. Thanks to the process of photosynthesis, $\mathrm{CO}_{2}$ is extracted from the atmosphere and the carbon is used as a one of the nutrients essential to building organic chemicals. The different organic chemicals produced constitute organic matter and can be stored in every part of the plant, however, the proportion of carbon contained varies enormously. Moreover, organic carbon can be sequestered and stored in forest soils. The amount of organic carbon in soils varies, depending on the surface. Carbon generally occurs in the partially decomposed vegetation- humus in the living organisms, in the fine roots and on the surface as well as upper soil layers $[10,11]$. Besides the problem of anthropogenic sources of $\mathrm{CO}_{2}$, it is also released from soil. Depletion of SOC is mainly caused by soil degradation processes and fertility - exploitative techniques in farming. External input of chemical fertilizers causes depletion of SOC in soils due to the lack of completion of nutrients, harvested in crops which leads to the mineralization of SOC $[9,12]$.

To enhance phytoremediation process as well as to increase the amount of soil organic matter, different organic amendments are used (organic wastes such as sewage sludge, biosolids, compost). Application of organic waste matter as amendments are becoming more commonly used practices, especially in large degraded areas including mined soils. Organic wastes constitute enormous energetic, economic and environmental challenges which have led to their extensive reuse as amendments to soils. Use of the compost as a soil fertilizer provides for soil organic matter. Moreover, using compost contributes to increasing organic carbon and microbial activity, a greater amount of nitrogen, phosphorus, potassium and magnesium. Due to the improvement of soil porosity, more water is available for plants and cation-exchange capacity can be noticed [13-17]. Another organic waste used in agricultural techniques is sewage sludge. Stabilized sewage sludge in the composting process can be used as a source of nutrients 
and soil conditioner in fields. Application of low toxicity sewage sludge has a potential as an organic amendment and fertilizers which should be given a priority [16-21]. Biosolids used for remediation increases soil organic matter, with subsequent effect on it, water retention capacity and $\mathrm{pH}$, buffer capacity and soil structure (aggregate stability, density, pore size). What is more, biosolids improve the biological activity and decrease soil erosion process. Single application of biosolid does not sufficiently increase organic matter and nutrients in soil, whereas the long-term and repeated application of sewage sludge can significantly improve the quality of soils. Some nutrients such as phosphate and potassium demand of agricultural soils can be covered by adequate biosolid application [16, 18]. Biosolids used for agro techniques should be tested for low concentration of heavy metals. Trace elements can enter in the food chain and biological circulation from soils and remain in the environment for long period of time, being resistant to chemical and biological degradation [19]. The natural process of carbon sequestration in degraded soils in highly complex and research results are not sufficient [1]. One of the appropriate solutions to a problem of mined soils is a combination of carbon sequestration, organic amendments as well as reforestation of degraded area.

The main aim of the study was to determine the effect of organic and inorganic amendments on heavy metal immobilization and organic carbon sequestration during phytoremediation of two degraded soils using Scots Pine and Giant Miscanthus.

\section{MATERIALS AND METHODS}

\section{Experimental plan, soil material, organic and inorganic amendments characteristics}

To investigate the impact of organic and inorganic amendments on phytoremediation of degraded soils and soil organic carbon sequestration, a growth chamber study over a period of one and half years was conducted. The pot experiment was carried out under controlled conditions of phytotron chamber. Soil materials (three replicates for combinations, $10 \mathrm{~kg}$ of soil for each pot), used in the study was collected from two degraded areas located in Poland: the area affected by a zinc smelter in Silesia region $\left(50^{\circ} 30^{\prime} 27.1^{\prime \prime} \mathrm{N} 18^{\circ} 56^{\prime} 09^{\prime \prime} \mathrm{E}\right)$ and from brown coal post-mining area (51 $15^{\prime} 54^{\prime \prime} \mathrm{N}$ $19^{\circ} 4^{\prime} 41^{\prime \prime}$ E). Investigated soils differed mainly in soil carbon content (higher for zinc smelter soil) and $\mathrm{pH}$ value (very low for zinc smelter soil). In this experiment two plant species: forest species [Scots Pine (Pinus Sylvestris L.)] and energy crops [Giant Miscanthus (Miscanthus $x$ Giganteus)] were used. Pots without plants were kept as control. The five organic and inorganic amendments, such as: Sewage sludge (Ss) from the food industry (15 Mg/ha on volume basis), First compost (Co1) from the biodegradable fraction of municipal waste $(15 \mathrm{Mg} / \mathrm{ha}$ on volume basis), Second compost (Co2) from sewage sludge from household wastewater treatment plant $(15 \mathrm{Mg} / \mathrm{ha}$ on volume basis), Coal slurry (Cs) from coal preparation plant (2\% on weight basis) and Lake Chalk (LC) from a brown coal mine ( $2 \%$ on weight basis), were used to determine the degree of immobilization of heavy metals and soil organic carbon sequestration in the soils. Table 1 shows the characteristics of organic and inorganic amendments.

Table 1. Selected chemical and physical parameters of soil amendments

\begin{tabular}{|c|c|c|c|c|c|}
\hline Chemical properties & Sewage sludge & $\begin{array}{l}\text { Compost (1) from Organic Fraction } \\
\text { of Municipal Solid Waste (OFMSW) }\end{array}$ & $\begin{array}{l}\text { Compost (2) from } \\
\text { sewage sludge }\end{array}$ & Coal slurry & Lake chalk \\
\hline $\mathrm{pH}\left(\mathrm{H}_{2} \mathrm{O}\right)$ & $6.1 \pm 0.1$ & $6.9 \pm 0.1$ & $6.4 \pm 0.1$ & $6.4 \pm 0.1$ & $7.3 \pm 0.1$ \\
\hline $\mathrm{C}$ total $\left[\mathrm{g} \mathrm{kg}^{-1}\right.$ d.m.] & $401.1 \pm 0.4$ & $295.1 \pm 6.2$ & $441.35 \pm 2.33$ & $364.1 \pm 5.5$ & $166.5 \pm 4.7$ \\
\hline N Kjeldhal [ $\mathrm{g} \mathrm{kg}^{-1}$ d.m.] & $39.7 \pm 0.3$ & $13.5 \pm 0.2$ & $14.0 \pm 0.1$ & $16.8 \pm 0.1$ & $17.4 \pm 0.1$ \\
\hline$P$ total $\left[\mathrm{mg} \mathrm{kg}^{-1}\right.$ d.m. $]$ & $5,197 \pm 16$ & $5,207 \pm 15$ & $1,781.96 \pm 6$ & $131 \pm 2$ & $169 \pm 2$ \\
\hline Cadmium (Cd) $\left[\mathrm{mg} \mathrm{kg}^{-1}\right.$ d.m.] & $0.7 \pm 0.1$ & $1.4 \pm 0.9$ & $0.49 \pm 0.2$ & $0.9 \pm 0.1$ & $0.4 \pm 0.1$ \\
\hline Lead $(\mathrm{Pb})\left[\mathrm{mg} \mathrm{kg}^{-1}\right.$ d.m. $]$ & $6 \pm 1$ & $40 \pm 3$ & $5.14 \pm 1$ & $38 \pm 2$ & $11 \pm 1$ \\
\hline Zinc $(\mathrm{Zn})\left[\mathrm{mg} \mathrm{kg}^{-1}\right.$ d.m. $]$ & $260 \pm 11$ & $453 \pm 14$ & $154.8 \pm 10$ & $174 \pm 11$ & $23 \pm 2$ \\
\hline $\begin{array}{c}\text { Polycyclic Aromatic } \\
\text { Hydrocarbons (PAHs) } \\
{\left[\mu \mathrm{g} \mathrm{kg}^{-1} \text { d.m.] }\right.}\end{array}$ & $1,766 \pm 23$ & $5,095 \pm 52$ & $2,254 \pm 110$ & $845 \pm 41$ & $1,335 \pm 85$ \\
\hline
\end{tabular}




\section{Soil and biomass analysis}

In the pot experiment the soil samples were analysed according to Polish Standard (PN-ISO) for: $\mathrm{pH}$ in $\mathrm{H}_{2} \mathrm{O}$ suspension according to PN-ISO 10390:1997) [22], Total Kjeldahl Nitrogen (TN) according to PN-ISO 11261:2002 [23], total organic carbon by using a modified Tiurin method according to PN ISO 10694:2002 [24], total phosphorus according to PN ISO 11263:2002 [25], total heavy metals concentration after microwave digestion procedures by using hot Aqua Regia (according to Polish Standard PN-ISO 11047:2001) was analyzed for Cadmium $(\mathrm{Cd})$, Lead $(\mathrm{Pb})$, and Zinc (Zn) by Inductively Coupled Plasma Optical Emission Spectrometry (ICP-OES; Spectro apparatus) [26], the concentration of available heavy metal in the pore soil solution by using Diffusive Gradients in Thin films (DGT) method [27]. The total Polycyclic Aromatic Hydrocarbons (PAH) concentration was determined as described previously [28]. After a period of one and half years, plants were harvested and biomass recorded separately for roots and shoots. After measurement of fresh biomass weight of individual plants ( 2 plants from each pot), the biomass was dried $\left(105{ }^{\circ} \mathrm{C}\right.$ for $\left.1 \mathrm{~h}\right)$. The analysis of plant biomass was made according to Polish Standard PN-G-04560:1998P [29].

\section{RESUTS AND DISCUSSION}

\section{The impact of organic and inorganic amendments on organic carbon content and concentration of available heavy metals in soil}

The analysis of organic and inorganic soil additives indicated that selected amendments contain quite low amounts of heavy metals and thus can be classified as biosolids. Only for compost derived from organic fraction of municipal solid waste, the contents of metal elements were higher. Considering the PAH content, the highest values were found also for compost from Organic Fraction of Municipal Solid Waste (OFMSW). Whereas it is a waste of domestic origin associated directly with food, fairly high concentration of contaminants in it is surprising. Moreover, applied additives contain significant amounts of valuable organic carbon, phosphorus and nitrogen. This indicates that all used amendments are suitable for remediation purposes, according to standards and results obtained by other authors [28]. Two of the amendments, coal sludge and lake chalk (calcium carbonate based amendment), are highly mineralized, thus containing less organic carbon content.

The analysis of soil organic carbon after 18 months of the experiment indicated that growth of plants may increase the organic carbon content (Figure 1) in degraded soils. This phenomenon was confirmed by highest concentrations of soil organic carbon noted for some combinations with plants. Even for control pots, without any amendments, this effect of plants vegetation was noticed. Similar results were achieved by other authors $[1,16,17]$. It was also found that sewage sludge addition caused the least increase in soil carbon after one year of the experiment, compared to other amendments, despite the high initial carbon content. This was probably caused due to more mobile fractions of carbon in sewage sludge.

Moreover, the highest values of soil organic carbon content was found for Lake Chalk (LC) amended soils. The increased carbon sequestration was evident especially for the use of LC and plants, where the effect was more pronounced. For both types of soil, contaminated smelter soil (MS) and uncontaminated mine soil (B), the carbon sequestration process was observed, regardless of the level of soil contamination. Furthermore, this phenomenon was also noted in other research [17]. During the phytoremediation of degraded soil, conducted with soil additives and plants, the improvement of many soil parameters (including immobilization of heavy metals) was obtained. It is very important to indicate the direction of changes of some soil properties and to determine the mobility of selected trace elements, especially heavy metals, which 
may pose a threat to the environment. Organic and inorganic soil additives, used in the pot experiment, resulted in the improvement of soil parameters.
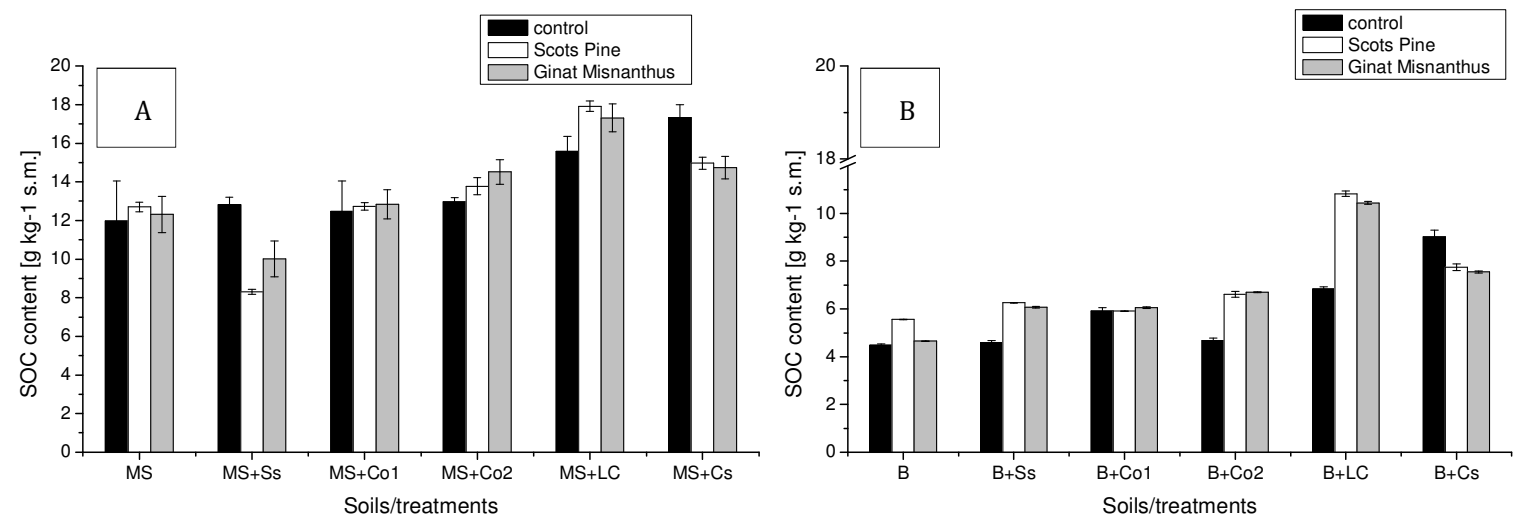

Figure 1. Changes in TOC content in zinc smelter soil (A) and coal mine soil (B), the letter combinations on X-axis stand for: Zinc smelter soil (MS), Brown coal mine soil (B), Sewage sludge (Ss), Municipal compost (Co1), Compost from sewage sludge (Co2), Coal slurry (Cs), Lake Chalk (LC)

Moreover, the decreasing bioavailability and phytotoxicity of heavy metals (zinc, lead, cadmium), and restoration of vegetation cover was observed (Figures 2-4). The results suggest that organic and inorganic additives, used in the experiment, may be a valuable fertilizer source for supporting plant growth and development in the phytoremediation of contaminated soils.

The area located in the neighborhood of zinc smelter was characterized by a high concentration of heavy metals (especially $\mathrm{Cd}, \mathrm{Pb}$ and $\mathrm{Zn}$ ) in soil, in contrast to the post-mining land. The immobilization process of heavy metals in contaminated soil, after the application of lake chalk, was observed. The reduction in the bioavailability of heavy metals in soils after application of lake chalk applies mainly to zinc and cadmium. However, some soil additives (e.g. compost from sewage sludge and coal slurry) may be a potential source of heavy metals. Some organic and inorganic additives could also lead to the leaching of heavy metals from contaminated soil, caused by lower soil $\mathrm{pH}$ after sewage sludge application. A similar effect was noted by other researchers [17, 28]. For this reason, the untreated sewage sludge should not be used for phytoremediation of heavy metals-contaminated soils.
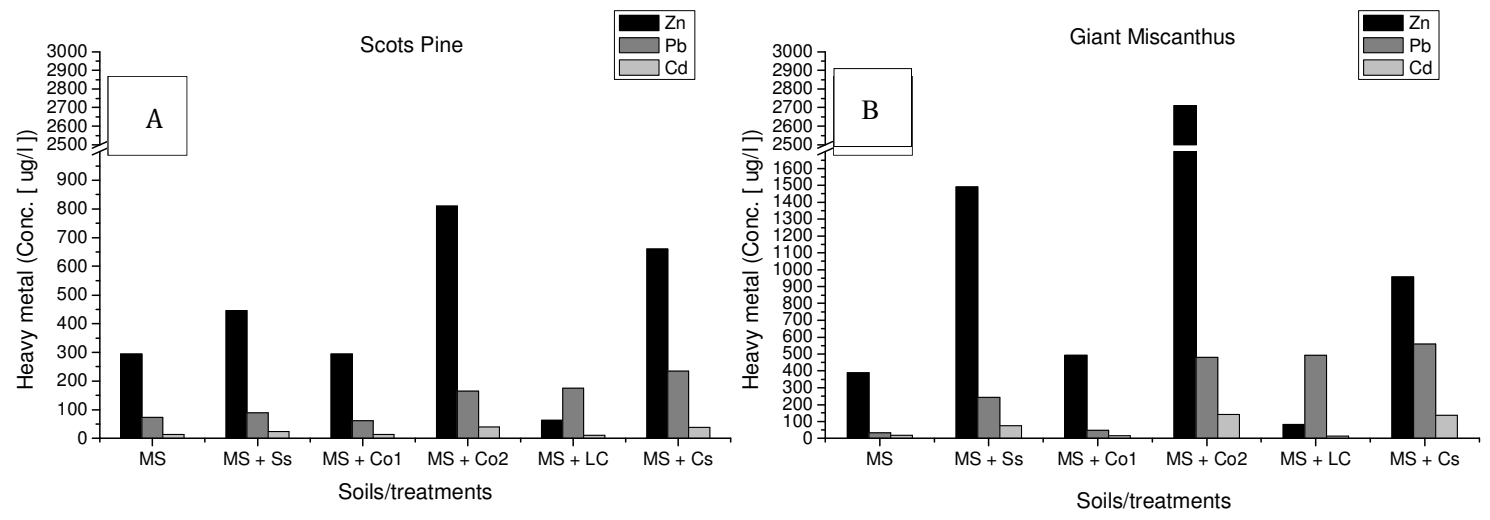

Figure 2. The bioavailability of heavy metals: Zinc $(\mathrm{Zn})$, Cadmium $(\mathrm{Cd})$, Lead $(\mathrm{Pb})$ in zinc smelter soil after growing Scots Pine (A) and Giant Miscanthus (B), the letter combinations on x-axis stand for: Zinc smelter soil (MS), Sewage sludge (Ss), Municipal compost (Co1), Compost from sewage sludge (Co2), Coal slurry (Cs), Lake Chalk (LC) 

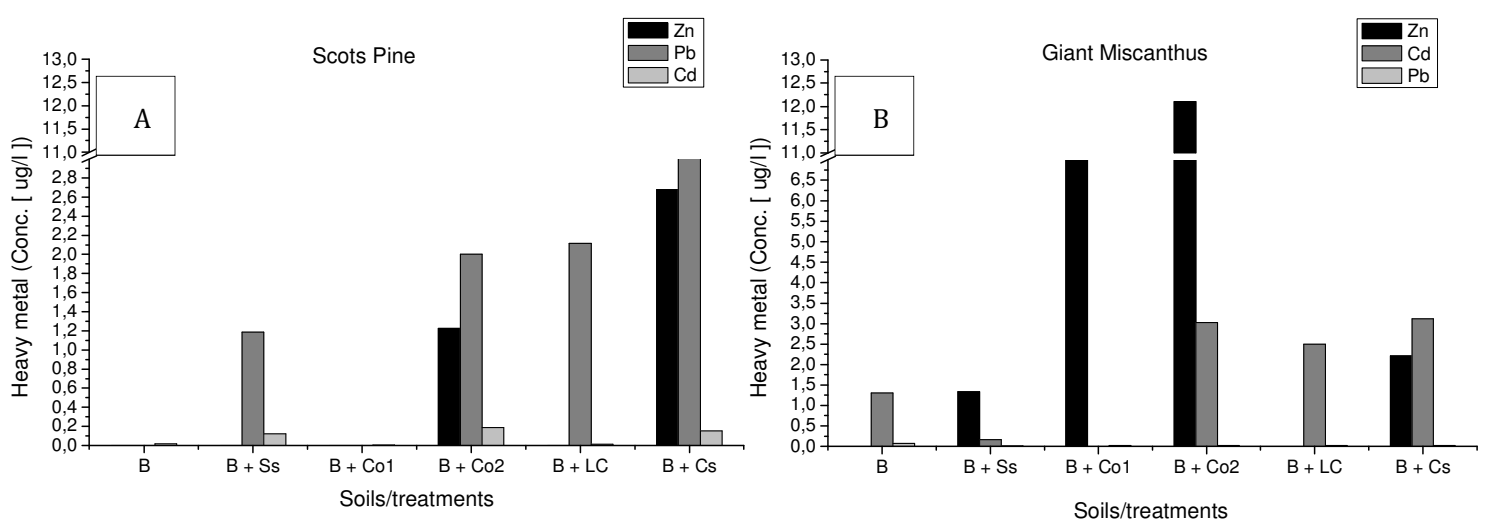

Figure 3. The bioavailability of heavy metals: Zinc $(\mathrm{Zn})$, Cadmium $(\mathrm{Cd})$, Lead $(\mathrm{Pb})$ in coal mine soil after growing Scots Pine (A) and Giant Miscanthus (B), the letter combinations on X-axis stand for: Coal mine soil (B), Sewage sludge (Ss), Municipal compost (Co1), Compost from sewage sludge (Co2), Coal slurry (Cs), Lake Chalk (LC)
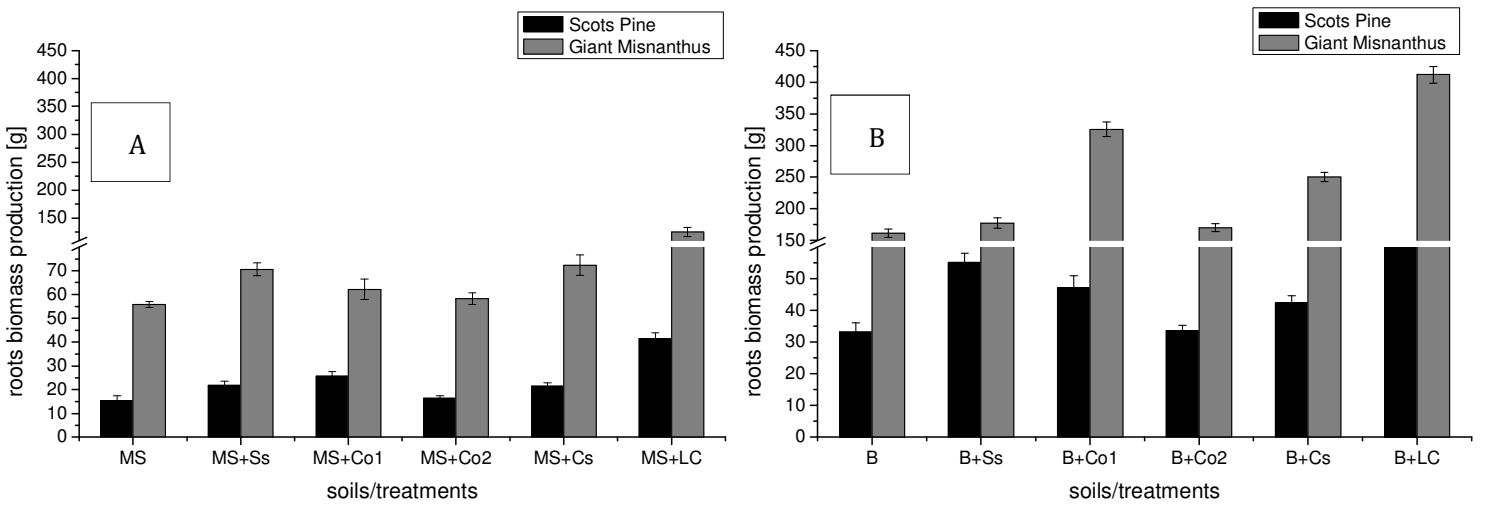

Figure 4. Roots biomass production of Scots Pine and Giant Miscanthus cultivated in smelter-polluted soil (A) and in post-mine soil (B), the letter combinations on X-axis stand for: Zinc smelter soil (MS), Brown coal mine soil (B), Sewage sludge (Ss), Municipal compost (Co1), Compost from sewage sludge (Co2), Coal slurry (Cs), Lake Chalk (LC)

\section{Root biomass production}

Higher plants biomass production for soils treatment with some organic and inorganic additives was noted. This phenomenon was especially observed for post-mining soil. Used sewage sludge, municipal compost and lake chalk improved the soil quality for healthy plant growth and development. Giant Miscanthus was characterized by an extensive root system (Figure 4). Moreover, higher root biomass production of Giant Miscanthus growing on uncontaminated soil (lignite mine soil) was recorded. Smaller differences between root growth of Scots Pine cultivated in smelter-polluted soil and in post-mine soil were observed. The largest root growth after the application of lake chalk to both soils was noted (Figure 4).

A similar improvement of root biomass production after fertilization of heavy metal contaminated soil with lake chalk was noticed (Figure 4A). This soil additive increases soil $\mathrm{pH}$ and reduces heavy metal mobility, which finally minimizes the harmful effect of metals on plant life and growth. At the same time, lake chalk has the lowest concentration of biogenic elements in comparison with other soil organic and inorganic additives. The obtained results confirm that the mobility of heavy metals in smelter-polluted soil has large impact on plant biomass production. These findings were also confirmed by other authors, who used liming as a remediation treatment [30]. This soil treatment also reduces the heavy metals mobility and thereby supports plant growth [31]. 
Root biomass production of Giant Miscanthus was significantly higher than Scots Pine root biomass for both soils. This may indicate better phytosequestration properties of Giant Miscanthus, especially in case land degradation due to mining and destruction of soil profiles.

\section{CONCLUSION}

The highest values of organic carbon content for lake chalk amended soil was noted. This phenomenon in both soils, contaminated smelter soil and uncontaminated mine soil, was observed. Moreover, the highest concentrations of soil organic carbon for some combinations with plants were noted. Therefore, growth of plants may increase the organic carbon content in degraded soils. Even for control soils, without any amendments, this effect of plants vegetation was noticed. Moreover, the application of sewage sludge caused the least increase in soil organic carbon content, after 18-months of the experiment, compared to other amendments. This was probably caused due to more mobile fractions of carbon in sewage sludge. During phytoremediation of degraded soils, conducted with Scots Pine and Giant Miscanthus, the immobilization of heavy metals was observed. The immobilization of heavy metals in smelter-polluted soil after the application of lake chalk was recorded. The reduction in the bioavailability of heavy metals in soils after application of lake chalk applies mainly to zinc and cadmium. However, some soil additives (e.g. compost from sewage sludge and coal slurry) may be potential sources of heavy metals. The results suggest that some organic and inorganic additives used in experiment may be a valuable fertilizer source for supporting plant growth and development. This phenomenon was especially observed for post-mining soil. The application of sewage sludge, municipal compost and lake chalk improved soil quality for healthy plant growth. Giant Miscanthus was characterized by an extensive root system.

\section{AKNOWLEDGEMENT}

The research has received funding from the Polish-Norwegian Research Programme operated by the National Centre for Research and Development under the Norwegian Financial Mechanism 2009-2014 in the frame of Project Contract No. (POL NOR/201734/76).

\section{REFERENCES}

1. Shrestha, R. K. and Lal, R., Ecosystem Carbon budgeting and Soil Carbon Sequestration in Reclaimed Mine Soil, Environment International, Vol. 32, No. 6, pp 781-796, 2006, https://doi.org/10.1016/j.envint.2006.05.001

2. Ruiz-Sinoga, J. D., Pariente, S., Diaz, A. R. and Martinez Murillo, J. F., Variability of Relationships between Soil Organic Carbon and Some Soil Properties in Mediterranean Rangelands under different Climatic Conditions (South of Spain), Catena, Vol. 94, pp 17-25, 2012, https://doi.org/10.1016/j.catena.2011.06.004

3. Lal, R., Soil Carbon Sequestration Impacts on Global Climate Change and Food Security, Sciencemag, Vol. 304, No. 5677, pp 1623-1627, 2004, https://doi.org/10.1126/science.1097396

4. Shi, X. Z., Wang, H. J., Yu, D. S., Weindorf, D. C., Cheng, X. F., Pan, X. Z., Sun, W. X. and Chen, J. M., Potential for Soil Carbon Sequestration of Eroded Areas in Subtropical China, Soil \& Tillage Research, Vol. 105, No. 2, pp 322-327, 2009, https://doi.org/10.1016/j.still.2008.12.016

5. Lal, R., Forest Soils and Carbon Seqestration, Forest Ecology and Management, Vol. 220, pp 242-258, 2005, https://doi.org/10.1016/j.foreco.2005.08.015 
6. Donevska, K., Jovanovski, J., Jovanovski, M. and Pelivanoski, P., Analyses of Environmental Impacts of Non Hazardous Regional Landfills in Macedonia, Journal of Sustainable Development of Energy, Water and Environment Systems, Vol. 1, No. 1, pp 281-290, 2013, https://doi.org/10.13044/j.sdewes.2013.01.0021

7. Anjum, N. A., Pereira, M. E., Ahmad, I., Duarte, A. C., Umar, S. and Khan, N. A., Phytotechnologies: Remediation of Environmental Contaminants, CRC Press Book, USA, 2012, https://doi.org/10.1201/b12954

8. Kuppens, T., Van Dael, M., Vanreppelen, K., Thewys, T., Yperman, J., Carleer, R., Schreurs, S. and Van Passel, S., Techno-economic assessment of Fast Pyrolysis for the Valorization of Short Rotation Coppice Cultivated for Phytoextraction, J. Clean. Prod., Vol. 88, No. 2, pp 326-344, 2015, https://doi.org/10.1016/j.jclepro.2014.07.023

9. Robert, M., Soil Carbon Sequestration for improved Land Management, Food and Agriculture Organization of the United Nations, Rome, Italy, 2001.

10. Wang, Y. F., Liu, L. and Shangguan, Z. P., Carbon Storage and Carbon Sequestration Potential under the Grain for Green Program in Henan Province, China, Ekol. Eng., Vol. 100, No. 3, pp 147-156, 2017, https://doi.org/10.1016/j.ecoleng.2016.12.010

11. Gorte, R. W., Carbon Sequestration in Forests, CRS Report for Congress, Congressional Research Service, 7-5700, 2009.

12. Lal, R., The Potential of Carbon Sequestration in Soils of South Asia, ISCO 2004-13 ${ }^{\text {th }}$ International Soil Conservation Organisation Conference- Brisbane, Australia, Paper no. 134, 2004.

13. Sabir, M., Zia-ur-Rehman, M., Hakeem K. R. and Saifullah, Phytoremediation of Metal-Contaminated Soils Using Organic Amendments: Prospects and Challenges, Soil Remediation and Plants, Prospects and Challenges, pp 503-523, 2015.

14. Yargiç, A. Ş., Yarbay-Şahin, R. Z., Özbay, N. and Önal, E., Assessment of Toxic Copper(II) Biosorption from Aqueous Solution by Chemically-treated Tomato Waste, J. Clean. Prod., Vol. 88, No. 2, pp 152-159, 2015, https://doi.org/10.1016/j.jclepro.2014.05.087

15. Scotti, R., Organic Amendments as Sustainable Tool to Recovery Fertility in Intensive Agricultural Systems, J. Soil Sci. Plant Nutr., Vol. 15, No. 2, pp 333-352, 2015, https://doi.org/10.4067/s0718-95162015005000031

16. Grobelak, A. and Napora, A., The Chemophytostabilisation Process of Heavy Metal Polluted Soil, PloSone, Vol. 10, No. 6, 2015, https://doi.org/10.1371/journal.pone.0129538

17. Kacprzak, M., Grobelak, A., Grosser, A. and Prasad, M. N. V., Efficacy of Biosolids in Assisted Phytostabilization of Metalliferous Acidic Sandy Soils with Five Grass Species, Int. J. Phytoremediation, Vol. 16, No. 6, pp 593-608, 2014, https://doi.org/10.1080/15226514.2013.798625

18. Sullivan, D. M., Cogger, C. G. and Bary, A. I., Fertilizing with Biosolids, A Pacific Northwest Extension Publication Oregon State University, Washington State University, University of Idaho, No. 508, Oregon State University, USA, 2015.

19. Laskar, M., Ali, S. and Siddiqui, S., A Potential Bio-Sorbent for Heavy Metals in the Remediation of Waste Water, Journal of Sustainable Development of Energy, Water and Environment Systems, Vol. 1, No. 1, pp 320-332, 2013, https://doi.org/10.13044/j.sdewes.2016.04.0025

20. Urbaniak, M., Wyrwicka, A., Tołoczko, W., Serwecińska, L. and Zieliński, M., The Effect of Sewage Sludge Application on Soil Properties and Willow (Salix sp.) Cultivation, Sci. Total. Environ., Vol. 586, No. 5, pp 66-75, 2017, https://doi.org/10.1016/j.scitotenv.2017.02.012

21. Urbaniec, K., Mikulčić, H., Duić, N. and Lozano, R., SDEWES 2014 - Sustainable Development of Energy, Water and Environment Systems, Journal of Cleaner Production, Vol. 130, No. 10, pp 1-11, 2016, https://doi.org/10.1016/j.jclepro.2016.04.062 
22. Anonymous Soil Quality - Determination of pH, PN ISO 10390:1997, Polish Committee for Standardization, 2002.

23. Anonymous Soil Quality - Determination of Total Nitrogen - modified Kjeldahl Method, PN ISO 11261:2002, Polish Committee for Standardization, 2002.

24. Anonymous Soil Quality - Determination of Organic and Total Carbon after Dry Combustion (Elementary Analysis), Polish Committee for Standardization, PN ISO 10694:2002 Carbon Determination, 2002.

25. Anonymous Soil Quality - Determination of Phosphorus - Spectrometric Determination of Phosphorus Soluble in a Solution of Sodium Bicarbonate, PN ISO 11263:2002, Polish Committee for Standardization, 2002.

26. Anonymous Soil Quality - Determination of Cadmium, Chromium, Cobalt, Copper, Lead, Manganese, Nickel and Zinc in Aqua Regia Extracts of Soil - Flame and Electrothermal Atomic Absorption Spectrometric Methods, PN ISO 11047:2001.

27. Almas, A. R., Lombnćs, P., Sogn, T. A. and Mulder, J., Speciation of Cd and Zn in Contaminated Soils assessed by DGT-DIFS, and WHAM/Model VI in Relation to uptake by Spinach and Ryegrass, Chemosphere, Vol. 62, No. 10, pp 1647-1655, 2006, https://doi.org/10.1016/j.chemosphere.2005.06.020

28. Rorat, A., Włóka, D., Grobelak, A., Grosser, A., Sosnecka, A., Milczarek, M., Jelonek, P., Vandenbulcke, F. and Kacprzak, M., Vermiremediation of Polycyclic Aromatic Hydrocarbons and Heavy Metals in Sewage Sludge Composting Process, Journal of Environmental Management, Vol. 187, pp 347-353, 2017, https://doi.org/10.1016/j.jenvman.2016.10.062

29. Ścisłowska, M., Włodarczyk, R., Kobyłecki, R. and Bis, Z., Biochar to improve the Quality and Productivity of Soils, Journal of Ecological Engineering, Vol. 16, No. 3, pp 31-35, 2015, https://doi.org/10.12911/22998993/2802

30. Alvarenga, P., Gonçalves, A. P., Fernandes, R. M., de Varennes, A., Vallini, G., Duarte, E. and Cunha-Queda, A. C., Evaluation of Composts and Liming Materials in the Phytostabilization of a Mine Soil using Perennial Ryegrass, Sci. Total. Environ., Vol. 406, No. 1-2, pp 43-56, 2008, https://doi.org/10.1016/j.scitotenv.2008.07.061

31. Zhang, X., Xia, H., Li, Z., Zhuang, P. and Gao, B., Potential of Four Grasses in Remediation of $\mathrm{Cd}$ and $\mathrm{Zn}$ Contaminated Soils, Bioresour. Technol., Vol. 101, No. 6, pp 2063-2066, 2010, https://doi.org/10.1016/j.biortech.2009.11.065 